\title{
Przemoc hermeneutyczna. 0 analogicznej rekonstrukcji obecności
}

\author{
Katarzyna Gan-Krzywoszyńska \\ (Uniwersytet Adama Mickiewicza in Poznań, katarzyna.gan.krzywoszynska@gmail.com) \\ Piotr Leśniewski \\ (Uniwersytet Adama Mickiewicza in Poznań, grus@amu.edu.pl)
}

Na szczęście nie odpowiadam za wydanie na świat żadnego człowieka, jeśli już jednak ktoś znajdował się w mojej orbicie, brałam na siebie współodpowiedzialność za niego.

Maria Orwid (2006, s. 335)

Gdyby nie ciało, dialog nie byłby możliwy.

Józef Tischner (1998, s. 104)

Banach powiedział mi kiedyś: „Dobry matematyk widzi analogie pomiędzy twierdzeniami lub teoriami, ale najlepsi widzq analogie pomiędzy analogiami."

Stanisław Ulam (1996, s. 232)

\section{Wprowadzenie}

Reyes Mate w Traktacie o niesprawiedliwości definiuje pojęcie śmierci hermeneutycznej jako tej, która zadawana ofierze czy ofiarom po ich śmierci cielesnej i ma ona polegać na zacieraniu śladów zbrodni, zadanej krzywdy i cierpienia ofiar, na wymazaniu egzystencji ofiary $\mathrm{z}$ pamięci wszystkich pozostałych żyjących i przyszłych pokoleń. Jest zatem $\mathrm{w}$ tym rozumieniu kolejnym naruszeniem praw ofiary zrealizowanym dla zmaksymalizowania korzyści sprawcy krzywdy. Stąd Reyes Mate, w swojej koncepcji pamięci jako sprawiedliwości, opisuje śmierć hermeneutyczną jako polegającą na wymazaniu śladów zbrodni poprzez pozbawienie zbrodni znaczenia. Jego zdaniem, kultura zachodnia doprowadziła do perfekcji zdolność zadawania śmierci hermeneutycznej, którą określa także mianem uniewidaczniania (hiszp. invisibilización) zbrodni (Mate 2011, 214-218; Leśniewski 2014, ss. 3335; Gan-Krzywoszyńska, Leśniewski 2014).

Fundamentalne odróżnienie między niesprawiedliwością a nierównością w ujęciu Reyesa Mate, pozwala nam scharakteryzować każdą niesprawiedliwość jako akt przemocy - w tym także krzywdę zadaną również, bądź tylko po śmierci. Nierówność jest naturalna, atemporalna, nie pociąga za sobą odpowiedzialności i winy, jak na przykład katastrofy naturalne bądź pewne uwarunkowania naturalne, jak na przykład dziedziczenie chorób 
genetycznych w przypadkach niezawinionych przez nikogo. Niesprawiedliwość zaś jest spowodowana przez człowieka, w konkretnym miejscu i czasie oraz pociąga za sobą odpowiedzialność i winę. Odróżnienie to ma charakter fundamentalny, a pomijanie go - bądź świadome mieszanie tych pojęć - jest, zdaniem Reyesa Mate, jednym z najcięższych przewinień, a jednocześnie najbardziej wyrafinowanym przejawem przemocy hermeneutycznej (Mate 2011, s. 11).

Przyjmuje się często twierdzenie, iż przemoc fizyczna jest zjawiskiem zdecydowanie bardziej groźnym niż przemoc psychiczna, którą stosunkowo od niedawna bada się systematycznie i której profilaktyka - zarówno prawna, jak i społeczna - dopiero kształtują się. Warto przypomnieć, iż Maria Orwid wspomina, że badania Antoniego Kępińskiego związane z chorobą poobozową nie spotkały się $\mathrm{z}$ natychmiastowym odzewem i jeszcze w latach 70-tych XX wieku dziwiono się, iż należy w psychiatrii wyróżnić dziedzinę zdrowia psychicznego młodzieży (Orwid 2006, 159-179, ss. 232-243). W konsekwencji takich właśnie sytuacji przemoc hermeneutyczna, rozumiana analogicznie do śmierci fizycznej i śmierci hermeneutycznej według Reyesa Mate, może nie wydawać się równie istotna, gdyż nie powoduje bezpośredniego cierpienia cielesnego czy psychicznego. Nie dotyka ona ani ciała, ani psychiki człowieka, lecz jedynie pamięć po nim. Jest to jednak bardzo groźna forma przemocy, gdyż jej konsekwencje dotykają całych pokoleń, pociągając przy tym za sobą nierzadko ogromne cierpienie cielesne i/lub psychiczne. Dodatkowo, zrealizowany efektywnie akt przemocy hermeneutycznej umacnia sprawcę krzywdy w jego postawie wobec ofiar i w jego dalszych działaniach - często zachęca go do kontynuowania procederu. Należy wyraźnie podkreślić, iż sprawca krzywdy jest przekonany, że skoro powiodło się zatarcie wszelkich śladów niesprawiedliwości, a więc także odpowiedzialności i winy, nie ma zatem żadnego powodu, by krzywdziciel miał zaprzestać krzywdzenia i to szczególnie w tych przypadkach, gdy czerpie z tego doraźne korzyści.

\section{Perspektywa anamnestyczna i przemoc hermeneutyczna}

Pamięć zatem, pomimo niewspółmiernego do zadanej krzywdy zadośćuczynienia, staje się fundamentalnym minimum procesu „odzyskiwania” uczestnictwa zarówno ofiary, jak i sprawcy krzywdy w strukturach społecznych w imię dobra wspólnego. Projekt Reyesa Mate polega na opracowaniu takiej koncepcji sprawiedliwości, której głównym celem jest uchwycenie perspektywy, dosłownie „spojrzenia ofiar” (hiszp. mirada de la víctima). Rzecz jasna, pamięć o wszystkich przypadkach niesprawiedliwości przekracza zdolności umysłu ludzkiego, dlatego tym bardziej należy postawić pytanie następujące - jak można pomyśleć o oddaniu sprawiedliwości, o zadośćuczynieniu i o trafnej teorii sprawiedliwości, która miałaby uwzględniać również te przypadki niesprawiedliwości, które zostały już definitywnie 
zapomniane? To pytanie Reyes Mate określa wprost mianem głównego pytania filozoficznego (Mate 2011a, s. 42; Leśniewski 2014, s. 35).

Reyes Mate wyróżnia krzywdy, którym można zadośćuczynić (hiszp. reparables) i one mogą być zrekompensowane przez przynajmniej część społeczeństwa, która zachowało o nich pamięć. Uchwalane prawa w odniesieniu do pamięci historycznej, które mają na celu zadośćuczynić materialnie lub niematerialnie - społecznościom ofiar są widocznym krokiem w dobrym kierunku. Istnieją jednak przypadki niesprawiedliwości już nie do naprawienia (hiszp. irreparables), którym nie da się już zadośćuczynić - wtedy właśnie należy je upamiętnić krzywdy. Taki akt upamiętnienia stanowi jednocześnie uznanie długu wobec ofiar oraz jest wyrazem żałoby po nich i próbą przywrócenia ich godności. Jak wspomnieliśmy, taki akt upamiętnienia stanowi niezwykle skromną formę oddania sprawiedliwości, ma jednak fundamentalne znacznie.

Perspektywa anamnestyczna odnosi się do nieobecnych. Na tym polega zasadnicza różnica $\mathrm{w}$ stosunku do ujęć stosowanych $\mathrm{w}$ polityce. Polityka ze swej natury koncentruje się na potrzebach żyjących. Można zatem sformułować następujące pytania charakteryzujące cztery perspektywy badawcze: (1) Czy ta sprawa-wydarzenie została (trafnie) wyjaśniona? (perspektywa historyczna); (2) Czy w tej sprawie-wydarzeniu wymierzono i wykonano karę? (perspektywa prawna); (3) Czy owa sprawa-wydarzenie została z punktu widzenia potrzeb obywateli korzystnie umiejscowiona (hiszp. orientar) w narracji o przeszłości? (perspektywa polityczna); (4) Czy zadośćuczyniono (w pełni) wyrządzonej krzywdzie? (perspektywa anamnestyczna) (Mate 2011, s. 293).

Sprawiedliwość ze względu na dobro wspólne Reyes Mate określa mianem sprawiedliwości ogólnej (hiszp. justicia general). Aby uchwycić to zapomniane współcześnie rozumienie sprawiedliwości, należy przeciwstawić sprawiedliwości ogólnej przypadki niesprawiedliwości. Jedną $\mathrm{z}$ form niesprawiedliwości może być na przykład odmowa płacenia podatków. Stanowiłaby ona pewną postać niesprawiedliwości w odniesieniu do dobra wspólnego danej wspólnoty. Niesprawiedliwe w tym znaczeniu byłoby także uniemożliwianie rozwinięcia każdemu członkowi danej wspólnoty jego talentu, czyli tego, co w każdym jest najlepsze, gdyż na skutek takiego niemoralnego postępowania wspólnota zostaje pozbawiona wielu dóbr, które mogłyby w konsekwencji powiększyć dobro wspólne.

We współczesnym społeczeństwie pluralistycznym sprawiedliwość nie jest już rozumiana jako cnota, ale stanowi moralny fundament polityki. Inaczej rozłożone są zatem również akcenty. 0 ile dla starożytnych najważniejszą rolę przy określaniu tego, co sprawiedliwe odgrywała krzywda wyrządzona drugiemu, o tyle współcześnie główny nacisk jest położony na to, co przynamniej większość obywateli uważa za sprawiedliwe, a co - za niesprawiedliwe. Rzecz jasna, aby sprawiedliwość miałaby dotyczyć 
wszystkich obywateli, wszyscy oni muszą też brać aktywny udział w rozstrzyganiu kwestii i trudności z nią związanych. Następuje zatem przejście od treści terminu sprawiedliwość do procedury, czyli do sposobu wyboru takich a nie innych kryteriów tego, co sprawiedliwe (Mate 2011a, s. 30). Należy jednak wyraźnie podkreślić, iż mówimy tu o konsensusie, który jak zobaczymy dalej, należy paradoksalnie do procedur umacniających narracje totalizujące.

Warunkiem sprawiedliwości globalnej jest wielki postęp w zakresie tego, co można określić mianem dostępności przestrzennej. Sztywne granice terytorialne ustanowione przez poszczególne państwa ulegają zamazaniu, a na ich miejsce powstaje sprawiedliwość trans-terytorialna. Otwierają się też możliwości egzekwowania sprawiedliwości tranzytywnej. Ale swoim zakresem sprawiedliwość globalna obejmuje nie tylko tak wyjątkowe sprawy, jak zbrodnie przeciwko ludzkości, ale także kwestie tak codzienne, jak głód na świecie oraz ubóstwo. I to nie śmierć unicestwiająca ciało, lecz właśnie bieda jest złem radykalnym (Levinas 1998, ss. 279-285). Na śmierć cielesną niewiele można zaradzić, natomiast przeciw biedzie możemy wszystko, dlatego stanowi ona ogromne wyzwanie dla całej ludzkości. Zdaniem Reyesa Mate, nie sposób poważnie rozprawiać o człowieczeństwie, jeśli bieda dzieli gatunek Homo sapiens na dwie kategorie - biednych „podludzi” (niem. Untermenschen) i bogatych „nadludzi” (niem. Übermenschen). Zdecydowanie obu tym kategoriom przysługuje bowiem ta sama własność - nie-ludzkość (bestialstwo). Nikt nie osiąga człowieczeństwa na własny rachunek. Biedak staje się człowiekiem w tym samym stopniu, w jakim ktoś, kto jest zamożny „od-bogaca” się (hiszp. des-enriquece) - i podobnie, bogacz w takim stopniu staje się człowiekiem, jakim biedak „od-ubaża” się (hiszp. des-empobrece). Reyes Mate zdecydowanie podkreśla, iż zniesienie takiej niesprawiedliwości jest możliwe wyłącznie pod warunkiem, że obecne podmioty wezmą na siebie odpowiedzialność za krzywdy powstałe w konkretnym czasie i miejscu (Mate 2011, s. 297).

Oczywiście wiele opisów i analiz przykładów eksterminacji, ludobójstw, krwawych kolonizacji skupia się na zadanych mordach, gwałtach, torturach i nadużyciach, nawet zniszczeniach dóbr kultury, lecz należy także poświęcić wiele uwagi konsekwencjom takim jak, w przypadku kolonizacji po pierwotnej inwazji i zniszczeniach, nadchodzi kolonizacja ekonomiczna, której następstwem jest kolonizacja kulturowa. Mimo, iż są te procesy pozornie mniej krwawe, w praktyce dopełniają dzieła nieodwracalnej zagłady, a ich konsekwencje odbijają swoje piętno przez całe stulecia. Enrique Dussel opisując kolonizacje Ameryki Łacińskiej wskazuje na motywacje które towarzyszyły „mniej krwawemu” etapowi kolonizacji ekonomicznej. Gdy okazało się, iż bardziej opłaca się eksploatować niż zabijać ludność miejscową, sprowadzono ich do roli niewolników, bądź taniej siły roboczej. Następnie kolonizatorzy uznali, iż dla czerpania ciągłych korzyści, wystarczy dominacja 
kulturowa - zwieńczona utrwaleniem poczucia niższości u kolejnych pokoleń autochtonów.

Przemoc hermeneutyczna pozornie więc nie dotyczy ciała, lecz stanowi w rzeczywistości przemoc wobec całych pokoleń i jest dziedziczona niczym kod DNA, powodując cierpienia cielesne i duchowe kolejnych generacji. Zatem przemoc fizyczna i psychiczna są czymś innym niż przemoc hermeneutyczna, lecz ta ostatnia może i powoduje przemoc fizyczną i psychiczną wobec znacznie większej liczby faktycznych ofiar. Pamięć zatem może być w tym sensie rozumiana jako sprawiedliwość wobec ciała.

\section{Perspektywa analogiczna}

Pojęcie analogii umożliwia optymalne rozwiązanie problemu wieloznaczności, wszechobecnego zwłaszcza w naukach humanistycznych. Rzecz jasna, stwierdzenie, że wszystkie pojęcia takie, jak lud, władza czy sprawiedliwość są wieloznaczne jest banalne. Tymczasem kluczowy jest pogląd - a nie jest to przy tym opinia zbyt powszechna - iż wspomniane pojęcia są pojęciami analogicznymi i wszelki dialog i racjonalność działań oraz ich wyjaśnianie zależą od zaakceptowania analogii jako najtrafniejszej strategii pozwalającej na przezwyciężenie problemu wieloznaczności. Poniżej zostanie przestawione krótkie wprowadzenie do pewnej propozycji ujęcia analogii i - konsekwentnie - perspektywy analogicznej, opracowane i rozwijane przez Enrique Dussela oraz Mauricio Beuchota.

Dussel, wybitny filozof pochodzenia argentyńskiego, jeden z „ojcówzałożycieli" filozofii wyzwolenia (hiszp. Filosofia de la Liberación) jest twórcą metody analektycznej. Nazwa wspomnianej metody ma wyrażać połączenie podejścia analogicznego i dialektyki, przy czym ów ostatni termin - w rozumieniu Dusselowskim - odnosi się ogólnie do aspektów diachronicznych przedmiotów badań.

Dussel wyróżnia trzy zasadnicze modele stanowisk wobec kwestii wieloznaczności. Te trzy stanowiska $\mathrm{w}$ artykule niniejszym proponujemy określać odpowiednio mianem podejścia monosemicznego, podejścia analogicznego oraz podejścia ekwiwokacyjnego.

Podejście monosemiczne (hiszp. unívoco) - charakteryzujemy za pomocą dwóch podstawowych kategorii - identycznością (hiszp. identidad) oraz różnicą (hiszp. differencia). W tym przypadku Dussel mówi o myśleniu totalizującym. W odniesieniu do problemu wyrażeń o wielu znaczeniach zakłada się, iż istnieje tylko jedno uprawnione znaczenie a każde inne jest zwalczane jako błędne, nieprawidłowe itd. Opowiadanie się za takim stanowiskiem powoduje, iż wszelki dialog jest wykluczony - istnieją bowiem tylko dwie możliwości („za” lub „przeciw”, „taki sam” albo „inny”), które są niezwykle wyraźnie, czy wręcz radykalnie określone aksjologicznie. Warto podkreślić, iż Dussel zalicza do przykładów takiego właśnie stanowiska 
monosemicznego nie tylko myślenie pozytywistyczne, ale całą tradycję filozoficzną - „od Jonii do Jeny” (w sensie Franza Rosenzweiga). W ramach stanowiska monosemicznego mieszczą się wszelkie postaci myślenia totalizującego (którego celem jest myślowa rekonstrukcja Całości, innymi słowy - uniwersum metafizycznego) i/lub unifikującego (czyli takich projektów filozoficznych, w których wyjaśnianie elementów uniwersum polega na sprowadzeniu ich do jednej zasady).

Warto także zwrócić uwagę, iż Dussel do tradycji myślenia totalizującego zalicza projekt Lévinasa. Obecne w propozycji Lévinasowskiej fundamentalne przeciwstawienie „Ja/Inny” miałoby - wedle opinii Dussela nosić znamiona groźnej opozycji „identyczność/różnica”. Inny jest bowiem całkowicie różny, jest zewnętrznością radykalną, zatem - według Dussela m.in. poprzez użycie tych kategorii ów projekt wpisuje się tradycję, którą wiążemy ze stanowiskiem monosemiczne.

Druga ważna uwaga dotyczy rozumienia pojęcia konsensusu. W standardowym ujęciu procedur demokratycznych to pojęcie ma zdecydowanie pozytywne konotacje. Dussel natomiast podkreśla jego aspekt totalizujący. To dość zaskakujące stwierdzenie wiąże się jednak po prostu z ustaleniem (na mocy odpowiednich procedur demokratycznych) jednego i obowiązującego znaczenia na przykład określonych terminów. ${ }^{1}$ Okazuje się więc, iż pojęcie konsensusu - choć z reguły nie kojarzy się tendencjami totalizującymi - może prowadzić na przykład do podziału zbioru wszystkich definicji danego terminu na co najmniej dwa niepuste podzbiory. Pierwszy z tych podzbiorów zawiera dokładnie jeden element (obowiązującą definicję danego terminu), drugi - wszystkie pozostałe definicje (traktowane jako niepoprawne bądź nawet prawnie zabronione).

Zatem stanowisko monosemiczne jest podejściem radykalnym (granicznym) umożliwiającym sprowadzenie wszystkich znaczeń (na przykład danego terminu) do jednego i obowiązującego.

Na przeciwległym krańcu znajduje się model, który określa się mianem stanowiska ekwiwokacyjnego. Dopuszcza ono wszelkie możliwe interpretacje danego obiektu kulturowego, które są jednocześnie całkowicie niewspółmierne. Jednak - podobnie, jak w przypadku monosemiczne omawiane $\mathrm{w}$ tym miejscu podejście uniemożliwia prowadzenie dialogu. Nie istnieje bowiem jakakolwiek płaszczyzna porozumienia. Moglibyśmy powiedzieć obrazowo, że zgodnie $\mathrm{z}$ owym podejście każda osoba ma swoją „prawdę", sformułowaną być może nawet w swoim własnym,

1 Rzecz jasna, moglibyśmy w tym miejscu mówić o znaczeniu dowolnego, ale ustalonego obiektu kulturowego (na przykład instytucji politycznej, dokumentu czy określonego procesu społecznego). Ograniczamy się - dla uproszczenia rozważań wyłącznie do terminów jako pewnych wyrażeń językowych. W dalszej części pracy piszemy już o dowolnych obiektach kulturowych. 
nieprzekładalnym języku. Skrajna idiosynkrazja niektórych stanowisk postmodernistycznych stanowiłaby trafną ilustrację takiego podejścia.

Zdaniem Dussela należy wskazać na umiarkowane stanowisko trzecie - na podejście analogiczne. Nie bez powodu jest ono nazywane „złotym środkiem". Wypada zdecydowanie podkreślić, iż opiera się ono na pewnym podobieństwie (hiszp. similaridad) łączącym - co najmniej dwa - rozważane przedmioty. Temu podobieństwu może towarzyszyć dowolna liczba odróżnienień (hiszp. distincción) - a nie różnic. Wspomnianego podobieństwa nie wolno mylić z identycznością. Zatem właśnie w podejściu analogicznym dialog jest możliwy i - za Beuchotem - mówimy nawet o racjonalność analogicznej. Warunkiem dialog jest przecież istnienie jakiejkolwiek, choćby minimalnej płaszczyzny porozumienia. Taka płaszczyzna stanowiąca owo łączące uczestników sytuacji dialogicznej podobieństwo pozwala wyjaśnienie innych znaczeń. ${ }^{2}$ Zarówno Beuchot, jak i Dussel, podkreślają prymat kategorii odróżnienia w ich ujęciu analogii. ${ }^{3}$ Ten drugi jednak wyraźnie podkreśla, że poszukiwaniu podobieństw powinno towarzyszyć zdawanie sprawy $\mathrm{z}$ wszelkich odróżnień między rozważanymi obiektami. Wspomniana metoda analektyczna zakłada przy tym diachroniczny aspekt analogii. Struktura danej analogii (obejmująca zarówno podobieństwa, jak i różnice między obiektami) może podlegać zmianom i badanie takich transformacji stanowi równie ważny przedmiot dociekań analektycznych. ${ }^{4}$ Niezwykle istotną kwestię stanowi także pojęcie przejrzystości czy klarowności. Przyjmuje się standardowo, iż te pojęcia są zarezerwowane dla badań podejmowanych zgodnie $\mathrm{z}$ podejściem monosemicznym. Dussel jednak wskaże, iż tylko stanowisko analogiczne gwarantuje podanie pełnej charakterystyki semantycznej danego obiektu kulturowego (na przykład danego wyrażenia językowego) z uwzględnieniem wszystkich niuansów znaczeniowych związanych z owym obiektem. Zatem tylko takie właśnie podejście umożliwia przede wszystkim jednak porównywanie odmiennych znaczeń i interpretacji rozważanych obiektów kulturowych. Co więcej, możemy im przypisywać zarówno wartości pozytywne, jak i negatywne. ${ }^{5}$

Przechodzimy w tym miejscu do uwag związanych z konsekwencjami politycznymi omawianych koncepcji. W kontekście eurocentryzmu Dussel zauważa, iż metoda analektyczna stanowi najtrafniejsze podejście

\footnotetext{
2 Jerzy Kmita - odwołując się, rzecz jasna, do terminologii Ajdukiewiczowskiej - pisał o wspólnej perspektywie świata (zob.: Kmita 2000, s. 6).

3 Warto podkreślić, iż Beuchot używa pojęcia różnicy w odniesieniu do analogii.

4 Dla porządku odnotujmy, iż kontynuując Ajdukiewicza program epistemologii semantycznej, Roman Suszko opracował i rozwijał projekt logiki diachronicznej, która była pierwszym systematycznym zastosowaniem semantyki teoriomodelowej w badaniach nad dynamiką wiedzy naukowej.

5 Niech nam będzie wolno przypomnieć, iż w środowisku Poznańskiej Szkoły Metodologicznej Włodzimierz Ławniczak zdecydowanie określał wprost nauki humanistyczne mianem nauk aksjologicznych.
} 
umożliwiające przezwyciężenie dominacji centrum nad peryferiami - i to $\mathrm{w}$ każdym aspekcie tej opozycji (czyli zarówno w odniesieniu do relacji dominacji zachodzącej między ustalonymi jednostkami, jak i w stosunku do owej relacji między większymi całościami społeczno-politycznymi). Jednocześnie takie podejście należałoby zastosować wobec wszelkiej przemocy. Chodzi bowiem o zdecydowane przekroczenie i odrzucenie podejścia totalizującego (hiszp. totalidad totalizante), które $\mathrm{w}$ praktyce pozbywa się bądź wykorzystuje jako podległe wszelkie byty nie mieszczące się w ramach jednej wizji uniwersum metafizycznego, bądź nie dające się sprowadzić do jedynej zasady organizującej strukturę owego uniwersum..

Podobnie Beuchot $\mathrm{w}$ swoim programie hermeneutyki analogicznej postuluje przede wszystkim, by w procedurach interpretacyjnych wprowadzić zhierarchizowany zbiór kilku uzasadnionych interpretacji. Nie akceptuje się więc ujęcia, zgodnie z którym dopuszczalna jest tylko jedna interpretacja i jednocześnie występuje się przeciw dopuszczeniu wszelkich, dowolnych interpretacji. Beuchotowska hermeneutyka analogiczna - określana również po prostu mianem semantyki analogicznej - to także stanowisko pośrednie między podejściem monosemicznym i podejściem ekwiwokacyjnym. Rzecz jasna, z jednej strony z pełną świadomością metodologiczną rezygnujemy z precyzji wiązanej tradycyjnie $\mathrm{z}$ monosemicznością, $\mathrm{z}$ drugiej zaś strony odrzucamy „otwartość”, której podstawą jest ekwiwokacja. Wedle propozycji Beuchota chodzi przede wszystkim o to, aby zapobiec skrajnościom, na które narażone są procedury interpretacyjne. Wspomniane powyżej podejścia ekstremalne uniemożliwiają efektywny dialog i prowadzą niezwykle często krwawych konsekwencji. Być może wypadałoby zgodzić się z poglądem, iż ofiarom tych nietrafnych interpretacji winniśmy zatem oddać sprawiedliwość i opracowywać konstrukcje przestrzeni dialogicznych opierając się na Dusselowskiej metodzie analektycznej i Beuchotowskiej hermeneutyce analogicznej.

\section{Przemoc hermeneutyczna jako dziedzictwo monosemiczności}

W ujęciu Dussela i Reyesa Mate do przemocy hermeneutycznej dochodzi, gdy mamy do czynienia z myśleniem w perspektywie monosemicznej - zarówno w wymiarze indywidualnym, jak i społeczno-politycznym. W sytuacji, gdy kategoriami podstawowymi są jedynie identyczność (innymi słowy tożsamość) i różnica, każda „inność” jest represjonowana, gdyż uznaje się, iż nie zasługuje ona na przywileje wynikające z przynależności do pewnej ściśle określonej całości stanowiącej podstawę identyfikacji (utożsamienia). Pełnia praw i przywilejów obowiązuje tylko „nas” (i/lub „naszych”), na przykład naszą płeć, rasę, kulturę, pochodzenie, etc. Każdy, kto znajduje się „za zewnątrz" jest zagrożony, zwłaszcza wtedy, gdy chciałby kwestionować 
prerogatywy przysługujące „naszym”. Podobnie, krzywdy są ważne tylko po jednej, „naszej” stronie - osoby poza „naszą” grupą to „barbarzyńcy”, wykluczeni, niżsi, gorsi, dzicy, poddani, niewolnicy, służący - w każdym z tych przypadków „ci, których nie bierzemy nawet pod uwagę”.

W tym kontekście - właśnie z powodu zakładanej monosemiczności kategorii identyczności (tożsamości) - trudno rozważać jakąkolwiek możliwość odwołania się do współczucia, miłosierdzia, litości gdyż, nie uznaje się w tych przypadkach niesprawiedliwości, tylko „naturalne” nierówności, bądź „nieuniknione koszty” postępu. Dlatego, w konsekwencji Dussel zastępuje tradycyjnie rozważane systemy polityczne (wśród nich wymieńmy na przykład demokrację, ochlokrację, oligarchię oraz monarchię) parą dwóch opozycyjnych systemów - systemowi dominacji zostaje przeciwstawiony system wyzwolenia. Pierwszy z tych systemów charakteryzujemy zwięźle jako „panowanie silniejszego” i mamy z nim do czynienia właściwie w każdej grupie społecznej, w najmniejszej społeczności począwszy od rodziny. Słabszy - na przykład kobieta, dziecko, ubogi - ma inną pozycję w strukturze grupy, nie liczy się tak, jak silny mężczyzna, bogaty, młody. Osoby należące do odmiennych grup w systemie dominacji nie mają tych samych praw. Nie zauważa się rzeczywistych analogii między osobami należącymi do przeciwstawnych grup $\mathrm{w}$ systemie dominacji, albo wskazuje się na podobieństwa nieistotne, nietrafne czy - po prostu - takie, które są wyłącznie urojonymi wymysłami i nie odpowiada im nic w rzeczywistości. W danym systemie dominacji przyjmuje się, iż kobieta jest własnością mężczyzny, podobnie, jak jego własnością jest pies czy koń, zatem mężczyzna ma prawo decydować o losie kobiety.

Warto zauważyć w tym miejscu, iż Reyes Mate wskazuje wyraźnie na pewne związki zachodzące między totalitaryzmem i myśleniem idealistycznym (oraz wielkimi systemami składającymi się na tradycję idealistyczną). Gdy struktura uniwersum metafizycznego zostaje sprowadzona do jednej tylko zasady (stanowiącej „pełnowartościowe” centrum uniwersum), wówczas każdemu elementowi, który w ramach owego uniwersum zajmuje pozycję poza centrum przysługuje istnienie nie $\mathrm{w}$ pełni wartościowe (jako bytowi niesamoistnemu, pochodnemu, podporządkowanemu czy służebnemu), bądź odmawia się takiemu elementowi w ogóle istnienia. Przezwyciężenie takich modelowych struktur hierarchicznych okazuje się niezwykle trudne zarówno w myśleniu teoretycznym, jak i w praktyce. Ale na przykład już 500 lat temu m.in. Montesinos i De las Casas szukali analogii podstawowej umożliwiającej podważenie czy nawet „rozbicie” rzekomej hierarchii między dwoma społecznościami, gdy stawiali pytanie, czy ludy podbite nie składają się z podobnych istot ludzkich, tak jak i konkwistadorzy (Mate 2011, ss. 298-300).

W kontekście owego „myślenia hierarchicznego” niech będzie nam wolno wspomnieć tragiczną historię życia Sary Baartman oraz zjawisko 
„ludzkich zoo” (ostatni pomysł pochodzi z 2005 roku z Niemiec) (zob.: BBC 2005). Te dwa przykłady ilustrują konsekwencje przemocy hermeneutycznej (Zob.: Crais \& Scully 2009; Davie 2012). Śmierć Baartman - w wieku 25 lat nie stanowi bowiem końca znęcania się nad Jej ciałem, którego fragmenty - w tym wycięte genitalia zatopione $\mathrm{z}$ formalinie - były eksponatami paryskiego Musée de l'Homme aż do 1974 roku. Dopiero Nelson Mandela jako prezydent RPA wystąpił z prośbą o zwrot ciała, w celu należytego pochówku w ojczyźnie. Osiem lat zajęło Parlamentowi francuskiemu rozpatrzenie tej prośby i podjęcie ostatecznie pozytywnej decyzji. Co gorsze, owa prośba była rozpatrywana przez deputowanych jako sprawa „Repatriacji Hotentockiej Venus”. Posłużono się zatem pogardliwym określeniem - „imieniem”, które nadano Baartman w poniżających występach $\mathrm{w}$ cyrku $\mathrm{w}$ ramach niezwykle popularnych wtedy wśród elit europejskich freak shows (Mbeki 2002). Gdy Sarah Baartman przez całe swoje krótkie życie odmawiała rozebrania się do naga przez publicznością - za co wiele osób było gotowych zapłacić niemałe kwoty - intymne części Jej ciała wystawiono jako „ciekawostki” naukowe. Współcześnie powstały prace, filmy, artykuły i wiersze poświęcone tej tragicznej postaci i niektóre z nich zdobyły wiele nagród - jak np. film dokumentalny z 1998 roku „The Life and Times of Sara Baartman". Mogłoby się zatem wydawać, iż oddano cześć Jej pamięci. Jednak Natasha Gordon-Chipembere, która jest redaktorką książki z 2011 roku zatytułowanej Representation and Black Womanhood. The Legacy of Sarah Baartman twierdzi, iż Sarah Baartman jest wciąż poddana uniewidocznieniu. Czytamy: "'Several books have been published about her treatment and cultural significance. She has become the landscape upon which multiple narratives of exploitation and suffering within black womanhood have been enacted', wrote Gordon-Chipembere. She argued that, amid all this, Baartman 'the woman, remains invisible'” (Parkinson 2016). Jednocześnie, wspomniana praca ujmuje $\mathrm{w}$ różnorodnych perspektywach ponure dziedzictwo krzywd zadanych Sarze Baartman, a w szczególności konsekwencje przemocy hermeneutycznej, które trwają do dziś i - co więcej dotykają one współcześnie również takie kobiety, jak np. Michelle Obamę, których losy wydają się zupełnym przeciwieństwem tej tragicznej historii (Gordon-Chipembre 2011). Pogrzeb Sary Bartman odbył się dopiero 9 sierpnia 2002 roku. Dzień ten stał się w Narodowym Dniem Kobiet w RPA. W roku ubiegłym Jej grób oblano biało farbą. Stało się to kilka dni po usunięciu pomnika Cecila Rhodesa z terenu Cape Town University, który twierdził, m.in. iż „I contend that we are the first race in the world, and that the more of the world we inhabit the better it is for the human race" (Parkinson 2016). 


\section{W stronę rekoncyliacji}

Pamięć nie jest zatem sprawiedliwością - jest raczej początkiem procesu, którego zwieńczeniem jest rekoncyliacja (Mate 2011a, s. 43). Perspektywa anamnestyczna niczego bowiem nie reguluje, wręcz komplikuje sytuację, ponieważ - mówiąc metaforycznie - „otwiera rany”. Oczywiście, tak rozumiana pamięć może być, niestety, narzędziem zemsty. Reyes Mate domaga się zatem, by odwołując się do autorytetu pamięci, rozważyć ją konsekwentnie do końca - a to znaczy, że trzeba ujmować sprawiedliwość całościowo, innymi słowy: ad integrum tu i teraz. Ale takie całościowe podejście przekracza możliwości ludzkie. Rekoncyliacja w ujęciu Reyesa Mate miałaby być formą sprawiedliwości integralnej - w skromnych, ograniczonych przestrzeniach teraźniejszości.

W perspektywie anamnestycznej uobecniają się minione przypadki niesprawiedliwości to znaczy krzywdy wyrządzonej niewinnym osobom. Sprawą fundamentalną jest zawsze narracja - opowiedzenie o różnorodnych wyrządzonych krzywdach i zadanych cierpieniach. Należy również postawić pytanie o to, jak oddać sprawiedliwość poszczególnym ludziom, którzy zostali pokrzywdzeni. Rzecz jasna, słowem-kluczem jest w tym przypadku termin naprawa (hiszp. reparación) - te krzywdy, których nie można już, niestety, zrekompensować należy upamiętnić. W stosunku do krzywd publicznych słowami-kluczami są dwa terminy: (1) obywatelstwo, czyli efektywne uznanie, iż ofiara jest pełnoprawnym obywatelem danego społeczeństwa oraz (2) rekoncyliacja.

Zbrodnia polityczna pociąga za sobą zawsze głębokie pęknięcie struktur społecznych i prowadzi do zubożenia - również kulturowego społeczeństwa, w którego ramach została popełniona. Proces rekoncyliacji zgodnie z propozycją Reyesa Mate - polegałby na odzyskaniu dla społeczeństwa zarówno ofiar, jak i tych osób, które są sprawcami krzywdy (hiszp. victimarios). Ofiara zostaje przywrócona dzięki uznaniu politycznemu. Inaczej przedstawia się sytuacja sprawców krzywd. Rekoncyliacja jest niemożliwa bez przebaczenia - osoba, która jest sprawcą krzywdy musi ponieść pewne koszty, innymi słowy - musi spełnić określone warunki. Pierwszym z tych warunków jest uznanie przez nią swojej winy wobec ofiary (i społeczeństwa) oraz przyznanie, że krzywda wyrządzona ofierze była niesprawiedliwością. Warunkiem drugim jest chęć stawienia czoła swojej przeszłej przemocy wyrażająca się zarówno poprzez przyznanie się do winy (i poddanie się karze), jak i pragnienie wynagrodzenia krzywdy i udział w naprawieniu niesprawiedliwości lub $w$ jej upamiętnieniu. Wspomniane warunki składają się ostatecznie na przemianę moralną sprawcy krzywdy. Oczywiście, wypada przypomnieć, iż sprawiedliwość to nie tylko ukaranie sprawców - zdecydowanie ważniejsze jest to nastawienie, które opisujemy zwykle za pomocą metaforycznego zwrotu „pochylenie się nad ofiarą”. Wydaje się, iż współczesne narody i inne grupy społeczne muszą wraz z upływem 
czasu odkryć że to nie zapomnienie, lecz pamięć jest warunkiem wartościowszej koegzystencji (Mate 2011a, ss. 44-45).

Chcielibyśmy zatem przypomnieć, iż Dussel tak kończy swą monumentalną pracę Filozofia wyzwolenia:

An international division of the philosophical labor, assigning to diverse groups and countries distinct tasks, would permit us to begin a fruitful dialogue where uniformity of themes would not be demanded, nor would certain thematic objects be spurned because they are not relevant to one or another group. Respect for the other's situation begins with respect for the other's philosophical discourse. (Dussel 1985, s. 196)

Jako pewną ilustrację konsekwentnego stosowania podejścia analogicznego, jesteśmy skłonni - w charakterze podsumowania powyższych rozważań - wskazać na uderzającą odpowiedniość między parą dominacja/wyzwolenie a opozycją między wojną a logiką, o której Paul Valéry pisał: „Niech Pan po prostu zapamięta, że między ludźmi mogą zachodzić tylko dwie relacje: logika lub wojna. Zawsze należy żądać dowodu - dowód stanowi wyraz podstawowego szacunku, którego winien Pan oczekiwać. Jeśli Panu odmówią, niech Pan pamięta, że został Pan zaatakowany i wykorzysta się wszelkie środki, by zmusić Pana do posłuszeństwa" (Gan-Krzywoszyńska, Leśniewski 2016, s. 140).

\section{Literatura}

BBC. 2005. "Row over German Zoo's Africa Show." BBC News. URL: http://news.bbc.co.uk/2/hi/africa/4070816.stm. Retrieved on: 14.05.2012.

Beuchot, M. 2009. Tratado de Hermenéutica Analógica. México: Facultad de Filosofía y Letras (UNAM) / Ítaca.

Crais, C. C., P. Scully. 2009. Sara Baartman and the Hottentot Venus: A Ghost Story and a Biography. Princeton: Princeton University Press.

Davie, L. 2012. "Sarah Baartman, at Rest at Last." SouthAfrica.info URL: http://www.southafrica.info/about/history/saartjie.htm\#.WD9si7lDR hM. Retrieved on: 14.05.2012.

Dussel, E. 1996. Filosofía de la Liberation. Bogota: Nueva América.

Dussel, E. 1985. Philosophy of Liberation. New York: Orbis Books.

Gan-Krzywoszyńska K., P. Leśniewski. 2014. "The Culture of Memory: The Approach of Reyes Mate." Ethics in Progress, Vol. 5(2): 246-256.

Gan-Krzywoszyńska, K., P. Leśniewski. 2016. Kazimierz Ajdukiewicz (18901963). Poznań: Wydawnictwo Naukowe UAM.

Gordon-Chipembere, N. 2011. "Under Cuvier's Microscope: The Dissection of Michelle Obama in the Twenty-First Century." In N. Gordon-Chipembre 
(ed.) Representation and Black Womanhood. The Legacy of Sarah Baartman (pp. 165-180). New York: Palgrave Macmillan.

Kmita, J. 2000. Wymykanie się uniwersaliom. Warszawa: Oficyna Naukowa.

Leśniewski, P. 2014. Społeczeństwo dialogu. Prolegomena do teorii rekoncyliacji. Poznań: Kontekst.

Mate, R. 2003. Memoria de Auschwitz. Actualidad moral y política. Madrid: Editorial Trotta.

Mate, R., J. Mayorga. 2003a. "Los avidadores del fuego: Franz Rosenzeig, Walter Banjamin y Franz Kafka“. Isegoría, Vol. 23: 45-67.

Mate, R. 2009. La herencia del olvido. Madrid: Errata naturea.

Mate, R. 2011. Tratado de la injusticia. Barcelon: Anthropos.

Mate, R. 2011a. Por una justicia anamnética. Iglesia Viva, Vol. 247: 29-48.

Mbeki T. 2002. „Letter from the President.” Race Science. URL: http://web.mit.edu/racescience/in_media/baartman/baartman_mbek iletter.htm. Retrieved on: 14.05.2012.

Orwid, M. 2006. Przeżyć... i co dalej? Rozmawiaja Katarzyna Zimmerer $i$ Krzysztof Szwajca. Kraków: Wydawnictwo Literackie.

Parkinson, J. 2016. "The significance of Sarah Baartman." BBC News Magazine. URL: http://www.bbc.com/news/magazine-35240987. Retrieved on: 07.01.2016.

Ulam, S. M. 1996. Przygody matematyka. Przeł. A. Górnicka. Warszawa: Prószyński i S-ka.

Tischner, J. 1998. Spór o istnienie człowieka. Kraków: Wydawnictwo Znak. 


\author{
Katarzyna Gan-Krzywoszyńska \\ (Uniwersytet im. Adama Mickiewicza) \\ Piotr Leśniewski \\ (Uniwersytet im. Adama Mickiewicza)
}

Przemoc hermeneutyczna. O analogicznej rekonstrukcji obecności

\begin{abstract}
The aim of the paper is to analyze the relation between hermeneutic violence and univocal semantics. Furthermore, we argue that hermeneutic violence although it concerns post mortal time span is as much dangerous as physical and psychological violence, since hermeneutic violence affects even whole generations of victims. The article contains also a brief presentation of analogical perspective in contemporary philosophical conceptions by Enrique Dussel and Mauricio Beuchot. Following Reyes Mate we claim that memory is of fundamental importance of any adequate and effective theory and especially practice of justice.
\end{abstract}

Keywords: violence, hermeneutic death, analogy, memory

Ethics in Progress (ISSN 2084-9257). Vol. 7 (2016). No. 1, Art. \#15, pp. 214-227.

doi: 10.14746/eip.2016.1.13 